\title{
The constitutionalisation of international trade law
}

KLAUS ARMINGEON, KAROLINA MILEWICZ, SIMONE PETER AND ANNE PETERS*

\section{KEY MESSAGRS}

- Empirical research lends support to the idea of a 'multi-speed globe' of differentiated (fragmented) constitutionalisation, rather than a fully-fledged integrative constitutional process. 'Variable geometry' on the global scale could acknowledge irreconcilable differences between nation states.

- A prominent candidate for one fragment of this variable global constitutionalisation is the World Trade Organization (WTO). Constitutionalisation of the WTO means an evolution from constitution to constitutionalism within this organisation.

- A core constitutional issue is the public interest. The concept of 'public interest' can be used in various ways. Exception and limitation clauses play an important role in the constitutionalist reconstruction of international law.

- The WTO is so far only modestly constitutionalised, but could and should be further constitutionalised. Further constitutionalisation of the WTO should comprise the following reforms: upgrading non-trade concerns such as the environment in the treaty language itself, liberalisation in trade sectors in which poor countries can compete, empowerment of individuals by enabling at least indirect participation in secondary law-making (parliamentary dimension) and dispute settlement (direct effect), streamlining of the decision-making and law-making processes by reviving the legally available options for majority voting and judicial review of WTO acts.

\section{A. Introduction}

Over the past sixty years, international law has developed from a narrow system of inter-state norms of coexistence into a broader and organised"system of cooperation. One of the most essential developments has

* Individual Project No. 1 , 'Constitutionalism and multilayered governance'. 
been the growing number of multilateral treaties designed not only to set in place legal frameworks but also to promote cooperation in an interdependent world. This growing network of treaties has opened up non-traditional spheres of international law, touching on nearly all aspects of life of contemporary society. And as international law has developed in scope, new actors have been accepted as international legal persons on the international scene.

In recent years, the developments in international law have gained new momentum in the debate on global constitutionalisation. 'Constitutionalisation' is a shorthand term both for the emergence of constitutional law within a given legal order and for the spread of constitutionalism as a mindset. The concept of constitutionalisation implies that a specific type of constitution (or constitutional law), namely a constitutionalist constitution, can come into being and develop over time. It also implies that a legal text (or various legal texts) can acquire (or eventually lose) constitutional properties in a positive feedback process. A text can be more (or less) constitution-like and more or less constitutionalist. It may be, in short, a constitution-in-the-making. Also, constitutionalisation is multifactorial. The emerging constitutional profile of the international order might be well developed in one or more areas or even special branches of law, but underdeveloped in others. So the process of global constitutionalisation is not all-encompassing. It is contingent and path-dependent. Patterns of coexistence and cooperation persist even in a generally more constitutionalised world order.

The concept of global constitutionalisation has been mainly studied from a normative angle. ${ }^{1}$ First empirical evidence ${ }^{2}$ points to the fact that the macro-process of the constitutionalisation of international law does indeed comprise subprocesses of micro-constitutionalisation. Milewicz and colleagues, ${ }^{3}$ studying state commitment to so-called quasiconstitutional multilateral treaties made between 1945 and 2007 and containing institutional and organisational guidelines for inter-state relations and fundamental human rights provisions for individuals, provide

1 See J. Klabbers, A. Peters and G. Ulfstein, The Constitutionalization of International Law (Oxford University Press 2009). See for the different perceptions of constitutionalisation, T. Cottier and M. Hertig, 'The Prospects of 21st Century Constitutionalism' (2003) 7 Max Planck Yearbook of United Nations Law 261.

2 A first empirical attempt at the analysis of global constitutionalisation has been made by K. Armingeon and K. Milewicz, 'Compensatory constitutionalisation: A comparative perspective' (2008) 22 Global Society 179.

3 K. Milewicz, A. Bächtiger and A. Nothdurft 'Constitutional pluralism or constitutional unity? An empirical study of international commitment (1945-2007)' (2010) 36 Review of International Studies 305-336.

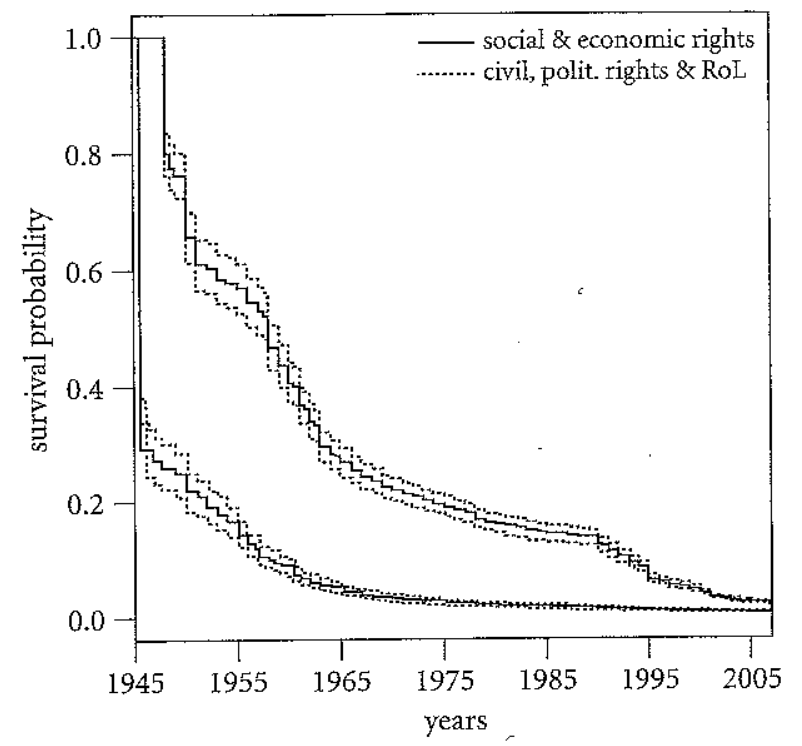

Figure 1.1 Ratification of quasi-constitutional multilateral treaties according to two issue-areas: (1) socio-economic treaties and (2) civil-political and 'rule of law' (RoL) multilateral treaties. Note: Survival probability refers to the probability that a state does not ratify a group of treaties.

grounds for the idea of a 'multi-speed globe' of differentiated microconstitutionalisation, rather than a fully-fledged integrative macroconstitutional process (see Figure 1.1).

Against this background, the present chapter focuses on the development of one sectoral constitution beyond the nation state, in particular within WTO law. The evolution of WTO law presumably constitutes, besides that of the EU, a prominent, but controversial case of microconstitutionalisation. ${ }^{4}$ We begin with a clarification of key concepts. We then discuss the most important aspects of the constitutionalisation of the WTO, notably the problem of democracy. We then focus on one particular aspect of WTO constitutionalism, namely the 'public interest' in WTO law. We argue that exception clauses in international law reflect the tensions between national concerns and international goals. From the point of view of global constitutionalisation these clauses reflect national public interest. We conclude that so far the WTO is only a modestly constitutionalised entity, but should and could be constitutionalised further.

4 See T Cottier and M Oesch, International Trade Regulation: Law and Policy in the WTO The European Union and Switzerland: Cases, Materials and Comments (Bern: Staempfli, 2005), Part Two 'Constitutional Principles of the WTO', pp. 346-574. 


\section{B. Key concepts and methdodological problems}

A constitutionalist vision of the WTO not only considers the world trade regime to have a constitution, but also to possess a constitutionalist constitution-in-the-making. This vision moves significantly beyond the older view that the founding acts of international organisations are 'constitutions'. For instance, long before the creation of the WTO, John Jackson had contemplated the 'constitutional structure of a possible international trade institution." This vocabulary is in line with the International Court of Justice (ICJ)'s view that '[f]rom a formal standpoint, the constituent instruments of international organisations are multilateral treaties... Such treaties can raise specific problems of interpretation owing, inter alia, to their character which is conventional and at the same time institutional. ${ }^{6}$ So the founding documents of international organisations have a hybrid character as treaty-constitution. ${ }^{7}$

This more traditional reading of the international organisations' founding documents did not rely on any material, value-laden (constitutionalist) principles, such as the rule of law or fundamental rights, but merely on the fact that the founding treaties established institutional structures, delineated the competences of the organisation, defined the terms of membership and the relations between the members and the organisation, regulated the organisations' core functions of law-making, conflict resolution and law enforcement, and laid down rules for the amendment of the founding treaties themselves. The doctrinal merit of this understanding of the law of international organisations was to

5 J. H. Jackson, World Trade Law and the Law of GATT, ch. 30:4 'The constitutional structure of a possible international trade institution' (Bobbs Merrill, Indianapolis, 1969), pp. 780-

6 Legality of the Use by a State of Nuclear Weapons in Armed Conflict, Advisory Opinion, ICJ Reports 1996, pp. 66 et seq., para. 19. See in the same sense ECJ, opinion 1/91, EEC, ECR 1991-I, 6079, 6102, para. 21. In scholarship notably R. Monaco, 'Le caractère constitutionnel des actes institutifs d'organisations internationales', in Mélanges offerts à Charles Rousseau: La communauté internationale (Paris: Pédone, 1974), p. 154, emphasis added.

7 This view has not been accepted by the Appellate Body. See AB, Japan - Taxes on Alcoholic This view has not been accepted by the Appellate Body. See AB, Japan - Taxes on Alcoholic Beverages (4 October 1996) WT/DS8/AB/R, WT/DS10/AB/R, WT/DS11/AB/R, p. 15: The
WTO Agreement is a treaty - the international equivalent of a contract. It is self-evident that in an exercise of their sovereignty, and in pursuit of their own respective national interests, the Members of the WTO have made a bargain. In exchange for benefits they expect to derive as Members of the WTO, they have agreed to exercise their sovereignty according to the commitment they have made in the WTO Agremeent.' overcome the outdated dichotomy between contract and constitution. ${ }^{8}$ But the constitutional view did not introduce a constitutionalist approach to the law of international organisations.

A constitutionalist approach - by contrast - seeks to identify and to advocate the application of constitutionalist principles, such as nondiscrimination, transparency, the rule of law, checks and balances, human rights protection, and possibly also democracy, to WTO law to improve the effectiveness and the fairness of the international trade order. So global constitutionalism, as applied to the WTO, has both descriptive and prescriptive elements.

We use 'WTO-constitutionalisation' as a shorthand term both for the gradual acquisition of constitutional and constitutionalist features (which overlays, but does not erase the character of the WTO-agreements as international treaties) and for the spread of constitutionalism as a mindset in analysing the WTO regime.

The academic objective of WTO constitutionalism is to identify the constitutional predispositions and indices in WTO law, to encourage reflection on how the process of WTO constitutionalisation might be broadened and intensified, and, in doing so, help to vindicate claims to a more constitutionalised world trade order. It not only purports to analyse the lex lata but also to argue de lege ferenda.

This agenda faces objections. The first is that WTO constitutionalism is too apolitical or pretends to be above politics and seeks to place economic freedoms above politics. ${ }^{9}$ The constitutionalist reading might be a scholarly attempt to channel or minimise politics. This is what Jeffrey Dunoff has aptly called 'constitutional conceits. ${ }^{10}$ Our response is that law and politics should not be viewed as distinct realms, but rather as structurally coupled systems. In particular, constitutional law and politics are mutually constitutive. In consequence, constitutionalism is also political, not simply 'an antidote to trade politics'11 (although it does

8 See on this dichotomy and its relevance for the debate on the legal nature of the EU Treaties, A. Peters, 'The Constitutionalisation of the European Union - Without the Constitutional Treaty', in S. Puntscher Riekmann and W. Wessels (eds.), The Making of a European Constitution (Wiesbaden: VS Verlag für Sozialwissenschaften, 2006), pp. 35-67.

9 R. Howse and K. Nicolaidis, 'Enhancing WTO legitimacy: Constitutionalization or global subsidiarity' (2003) 16 Governance 75. I. P. Trachtman, 'The constitutions of the WTO' (2006) 17 European Journal of International Law 623.

10 J. Dunoff, "Constitutional conceits: The WTO's "Constitution" and the discipline of international law' (2006) 17 European Journal of International Law 649, pp. 661-665 and p. 672.

11 Dunoff, above note 10, p. 661. 
suggest that there is a sphere 'above' everyday politics). Paradoxically, but in our mind laudably, the call for constitutionalism triggers precisely the contestation and politics it is said to pre-empt. The evolutionary dynamics of constitutionalism lead both to the legalisation of trade politics and to a stronger politicisation of trade law. Even if any legalisation of political problems (counting constitutionalisation as a special type of legalisation) modifies the debate surrounding these problems by introducing a different, juridical logic, the underlying issues are only partly depoliticised. Such a relative depoliticisation of international trade relations is not a disadvantage, but a plus. The introduction of legal and even constitutional principles contributes to the stability of expectations, legal certainty and equal treatment of the relevant actors (WTO Members and economic enterprises).

Both proponents and critics of the constitutionalist reading of WTO law agree that the turn towards constitutionalism is to some extent-an effort to find a legitimating principle for a system that faces a legitimacy gap: the WTO limits governmental policies without finding sufficient acceptance by the populations affected. ${ }^{12}$ However, as a response to the WTO's legitimacy crisis, constitutionalism might be fallacious. ${ }^{13}$ Is it only a rhetorical strategy to invest international trade law with the power and authority that domestic constitutional structures and norms possess? ${ }^{14}$ Does the constitutionalisation discourse serve to close the door against claims that the WTO has gone too far? If this were the case, the reification of the WTO would indeed backfire. It would only exacerbate the legitimacy crisis or stifle appropriate responses to it. It would also fuel the discontents of globalisation if it simply translated economic liberalism into higher lawirreversible, irresistible and comprehensive. ${ }^{15}$

However, the intrinsic link between constitutionalism and legitimacy works in many ways. Constitutionalism may legitimise the international trade system, but it may also challenge its legitimacy. On the one hand, the danger is that 'things formerly called institutional are being legitimized with the mantle of constitutionalization'. ${ }^{16}$ This is unhelpful in analytical

12 See M. Elsig, 'The World Trade Organization's legitimacy crisis: What does the beast look like?' (2007) 41 Journal of World Trade 75; D. C. Esty, 'The World Trade Organization's legitimacy crisis' (2002) I World Trade Review 7; also R. Howse, 'The legitimacy of the legitimacy crisis' (2002) 1 World Trade Review 7; also R. Howse, 'The legitimacy of the International Organizations (Tokyo: United Nations University Press, 2001), pp. 355-407. 13 Howse and Nicolaidis, above note 9 , p. 74 and p. 80.

14 Dunoff, above note 10, p. 649 . 15 Howse and Nicolaidis, above note 9, esp. p. 74. 16 D. Z Cass, Constitutionalization of the WTO (Oxford University Press, 2005), p. 245. terms and dangerous from a normative perspective. WTO constitution alism should not be used apologetically to bestow false legitimacy on international trade law. Nor should the complaint of a lack of legitimacy in international trade law undermine the authority of the WTO. Rather WTO constitutionalism should and could help rather than hinder the revelation of existing legitimacy deficiencies in world trade law without throwing the baby out with the bath water. There is, as Neil Walker put it, a 'responsibilising' potential in the constitutional discourse and imagination in the development of a polity. ${ }^{17}$ Those who wish, for whatever motives, to make a plausible claim to constitutional elements in WTO law, must at least be seen to take these values seriously. So although constitutionalism may be invoked as a way of closing the debate, in practice it often has the opposite effect, namely that of opening up a richer and more productive normative debate. The reason is that the tradition of constitutionalism remains the best-stocked reservoir from which responsible politics may draw and the most persuasive medium in which these politics may be articulated. ${ }^{18}$ So WTO constitutionalism deploys, and this is what we deem crucial, a constructive, not an obstructive, critical potential.

\section{How far has the WTO been constitutionalised to date?}

\section{Constitutional principles constraining Members}

One indicator and promoter of micro-constitutionalisation is the constitutional rights and principles. Historically, the General Agreement on Tariffs and Trade (GATT) was established on the ground that policies made in one country often adversely affect people in other countries who, in the absence of any institutional framework, have no ability to influence those policies. GATT was supposed to provide a forum in which one member could challenge the protectionist policies of another member. ${ }^{19}$ Such protectionist policies are widely seen to result from an undue influence of rent-seeking groups whose lobbyism is apt to damage the domestic democratic processes. Against this background, the WTO's core function is to

17 N. Watker, 'The EU and the WTO: Constitutionalism in a new key', in G. de Burca and J. Scott (eds.), The EU and the WTO: Legal and Constitutional Issues (Oxford: Hart, 2001), pp. 53-54.

18 Walker, above note 17, p. 57 .

19 P. M. Gerhart, 'The WTO and participatory democracy: The historical evidence' (2004) 37 Vanderbilt Journal of Transnational Law 897, p. 933. 
neutralise the domestic power of protectionist interests, and the WTO Members have thereby enabled themselves to overcome deficiencies in domestic political processes. ${ }^{20}$ This is a typically constitutional function, which is in the domestic realm served by fundamental rights guarantees and by judicial protection through constitutional courts.

In the current WTO, the traditional trade law principles of mostfavoured nation and national treatment operate against state failure in the form of protectionism. These principles are constitutive of the system of multilayered governance and thus may be considered as amounting to constitutional principles of the trading system. ${ }^{21}$ They constrain the WTO Members and are increasingly viewed as two facets of a constitutional principle of non-discrimination ultimately benefiting the ordinary citizens (such as importers, exporters, producers, consumers and taxpayers) ${ }^{22}$ Likewise, the transparency obligations imposed on the WTO Members by provisions such as Article X GATT and Articles III and VI General Agreement on Trade in Services (GATS) also seeek to prevent illegitimate protectionism and to that extent serve a constitutional function. ${ }^{23}$

However, these constitutional principles cannot be enforced by private actors. Although private operators currently have the possibility to influence WTO-related negotiations and also participate informally in WTO dispute settlement, ${ }^{24}$ they have no formal legal standing in this regard. Second, private actors are not able to enforce WTO rules in domestic courts, because most domestic courts, the European courts, and a WTO panel reject a direct effect of GATT. ${ }^{25}$ Most importantly, that panel

20 J. McGinnis and M. Movsesian, 'The World Trade Constitution' (2000) 114 Harvard Law Review 521

21 Cottier and Oesch, International Trade Regulation, above note 4, p. 346.

22 See E.-U. Petersmann, 'Multilevel judicial governance of international trade requires a common conception of rule of law and justice' (2007) 10 Joutnal of International Economic Law 533: 'the WTO guarantees of freedom, non-discrimination and rule of law - by enhancing individual liberty, non-discriminatory treatment, economic welfare, and poverty reduction across frontiers - reflect, albeit imperfectly, basic principles of justice.' 23 P. Delimatsis, International Trade in Services and Domestic Regulations: Necessity, Transparency, and Regulatory Diversity (Oxford University Press, 2007).

24 For example the WTO dispute raised by the USA against Japan concerning photographic film and paper has for this reason been perceived as a 'Kodak $v$ Fuji? dispute: Panel, Japan - Measures Affecting Consumer Photographic Film and Paper (3I March 1998) WT/DS44/R. See G. Shaffer, Defending Interests: Public-Private Partnerships in WTOLitigation (Washington, DC: Brookings Institution Press, 2003).

25 Panel, US - Section 30l-310 of the Trade Act of 1974 (27 January 2000) WT/DS152/R (not appealed) para. 7.72: 'Neither the GATT nor the WTO has so far been interpreted by deliberately distinguished the WTO regime from the EU and the van Gend \& Loos conception of an autonomous legal order by highlighting that ${ }^{\prime}$ the GATT/WTO did not create a new legal order the subjects of which comprise both contracting parties or members and their nationals. ${ }^{26}$

A different aspect of WTO rights-based constitutionalism is the suggestion to integrate human rights concerns into world trade law, not only through the interpretation of existing agreements, but also through the building of new common institutions. ${ }^{27}$ In fact, a constitutionalist approach is apt to provide a vocabulary, a theory and institutional building blocks to satisfy the quest for coherence between trade law and human rights law. The rights-based constitutionalist school submits that human rights have become guiding principles of international economic law. ${ }^{28}$ Proponents suggest endorsing a general maxim of interpretation of the GATT obligations of WTO Members (and the relevant exception clauses) in the light of human rights guarantees. ${ }^{29}$

The rights-based constitutionalist reading of WTO law has (to some extent erroneously) been perceived as narrow. It has been criticised for marginalising social rights and environmental principles and for focusing on economic and property rights. Early constitutionalist scholarship was therefore criticised as masking a radically economically libertarian free-trade agenda. In fact, the old GATT law neglected social and environmental issues and was geared towards negative integration by eliminating trade barriers. Today, the Agreement on Trade-related Aspects of Intellectual Property Rights (TRIPS), Article VI GATS, the Agreement on Technical Barriers to Trade (TBT Agreement) and the Agreement on the Application of Sanitary and Phytosanitary Measures (SPS Agreement), the Antidumping Agreement and the Agreement on Agriculture seek to achieve positive integration through common standards, even if very few of these standards marginally relate to the environment, and hardly relate at all to social aspects.

GATT/WTO institutions as a legal order producing direct effect [i.e. as creating enforceable rights and obligations for individuals].' It would be better to speak of an 'indirect effect' of GATT (para. 7.78). See also CFI, case T-174/00, Biret International SA v. Councit, ECT 2002 II-17, para. 62.

26 Panel, US - Section 301, above note 25, para. 7.72 .

27 T. Cottier, 'Trade and human rights: A relationship to discover' (2002) 5 Journal of International Economic Law 111.

28 Cottier and Oesch, International Trade Regulation, above note 4, p. 513.

29 E.-U. Petersmann, "Time for a United Nations "Global Compact" for integrating human rights into the law of worldwide organizations: Lessons from European integration' (2002) 13 European Journal of International Law 621, pp. 645-46. 
In defence of constitutionalism, it can be claimed that the constitutionalist reading of WTO law precisely supports the quest for the adoption of such standards. Moreover, trade liberalisation normally triggers a demand for positive integration. However, the WTO, in contrast to the $\mathrm{EU}$, currently lacks the institutions and means to complement the ongoing negative integration with positive integration..$^{30}$ Also, a large part of the membership opposes the WTO having any social agenda. And unlike the EU, the WTO does not have decision-making structures that easily. allow for variable geometry. To conclude, the 'constitutional' WTO principles addressed towards the WTO Members seem - for the time being to be too incomplete to confirm the descriptive claim that the WTO has been constitutionalised along these lines.

\section{Democracy}

The democratisation of international organisations is a key element of their constitutionalisation. ${ }^{31}$ Føllesdal argued 'that we find it conceptually difficult to disentangle legitimacy and democracy: legitimate modes of governance must be democratically accountable.' Only democratic systems that advocate the values of liberty and equality deserve the loyalty of their enlightened citizens in modern societies. ${ }^{32}$ This is not necessarily applicable to the large number of pre-modern societies, which do not support these values. However, if a global constitutional order needs legitimisation by the citizens in the economically most advanced nation states, only democratic rules pertaining to participation (government of and by the people) and to policy outputs in the common interest of the people (government for the people) may create this legitimacy.

By implication, a global constitutional order needs a democratic decision-making system for producing and developing global constitutional norms, both in general international law and in specific regimes such as that of the WTO. However, as convincingly argued by Michael Zürn, ${ }^{33}$ power and resource imbalances impede a system of equal rights

30 Howse and Nicolaidis, above note 9, pp. 84-5.

31 Markus Krajewski, 'International organizations or institutions, democratic legitimacy' Max Planck Encyclopedia of International Law (2009), para. 25.

32 A. Føilesdal, "When "common interests" are not common: Why the "global basic structure" should be democratic' (2009) 16 Indiana Joutnal of Global Legal Studies 585-604.

33 M. Zürn, 'Institutionalisierte Ungleichheit in der Weltpolitik: Jenseits der Alternativen "Global Governance" versus "American Empire" (2007) 48 Politische Viertelijahresschrift 680. in this constitutional order. There are no such rules as 'one individual one vote' or 'one nation state - one vote'. It is entirely unclear how preferences of states and preferences of individual citizens have to be aggregated. It is also unclear whether all states should have the same rights and powers. Some nation states have more duties and rights than others. They have different levels of influence on rule formation. They are treated differently. Cases in point are the veto rights of the five permanent members in the UN Security Council; privileges of the US with regard to the International Criminal Court;, ${ }^{34}$ weighted voting rights in the World Bank; the different risks of nuclear powers compared to other nations with regard to UN interventions; and the fuzziness of procedural rules on the international level and diffuse distributions of competencies among international organisations, allowing for opportunistic behaviour by nation states. Strong nation states have the opportunity of picking the international organisation and the sets of constitutional rules that are most compatible with domestic interests. The global constitution is still basically biased in favour of the most powerful countries, and in particular of the US. In this context Ulrich K. Preuss argued that the principle of sovereign equality of all states may be the first victim of the constitutionalisation of international law. ${ }^{35}$

In conclusion, there is so far no efficient global democratic system concerned with the further development of global norms and the control of their implementation. Even worse, there are no convincing ideas of how such a democratic system - which has to honour the democratic principles on the regional, the national and the international levels and its interactions - could and should look like. Hopes for a deliberative democracy depend on the absence of distributive conflicts and value conflicts - which is hardly realistic. Hopes for a new democracy, which are built on non-governmental organisations as agents and representatives of the people, depend on some democratic accountability of and equality of access to these organisations. At the moment there are no strong empirical arguments suggesting that this may be the case. Hence there is no convincing idea of what a workable and legitimate international democratic system should look like and which rights and powers should be allocated to individuals, regions, private organisations and nation states. On the

34 UNSC Res 1422 (12 July 2002) UN Doc S/RES/ 1422 and UNSC Res 1487 (12 June 2003) UN Doc S/RES/1487.

35 U. K. Preuss, 'Equality of states - Its meaning in a constitutionalized global order' (2008) 9 Chicago Journal of International Law 17. 
international level, there may be increasing changes in favour of the rule of the law, but few changes in favour of a combination of rule of law and democracy.

But what is the state of democratisation of the WTO? Here rules and decisions are made following procedures which do not include democratic elements in any meaningful sense. It has therefore been argued that, because of its inherent lack of democratic legitimacy, WTO law cannot serve constitutional functions. ${ }^{36}$ The WTO law-making processes can be called democratic only in a transitive way, to the extent that the democratic Members' representatives enjoy a democratic mandate and the domestic parliaments have approved the treaties. However, this type of transitive democratic legitimacy is rather weak, inter alia because not all WTO Members are democracies, and because in those that are democracies the role of parliament is basically limited to an affirmation of treaties concluded by the executives. ${ }^{37}$

\section{Rule of law: constitutional principles constraining the WTO}

Constitutionalists point out that the WTO itself is based on the rule of law, not only in terms of substance, but also in terms of procedure. While negotiations still largely follow politics and diplomatic traditions, the Dispute Settlement Understanding (DSU) provides for fair procedures in the administration of justice. ${ }^{38}$ However, the substantial rules and the dispute settlement procedures currently only work to subject the Members, not the WTO as an organisation, to the rule of law. A more developed rule of law requires that the WTO itself is bound by certain principles. Only then are the organisation's powers constitutionally limited. And to be effective, these constitutional limits must be enforceable. The acts of the organisation itself must be subject to judicial review, either by international or by domestic courts. Currently, only the EU possesses this in our view - crucial constitutionalist feature. The ECJ and the Court of First Instance (CFI) are competent to control the legality of the acts of the organs and institutions themselves. Fully fledged guarantees of human rights infringements by EU acts have been only gradually granted

36 M. Krajewski, 'Democratic legitimacy and constitutional perspectives of WTO law $^{3}$ (2001) 35 Journal of World Trade 167.

37 See for the problems of a transitive democratic legitimacy of global governance, A. Peters, 'Dual Democracy' in J. Klabbers, A. Peters, and G. UIfstein, The Constitutionalization of International Law (Oxford University Press, 2009), pp. 263-34.1.

38 Cottier and Oesch, International Trade Regulation, above note 4, p. 543. in a dialectical process triggered through opposition against European claims of authority by the Member States..$^{39}$ A parallel process has been set in motion with regard to the UN Security Council, whose comprehensive sanctions against Iraq since 1991 and more recent targeted sanctions against individuals risk violating social rights, procedural rights and property rights. Again, the threat of non-compliance by outside courts might push the United Nations to clearly acknowledge that the Security Council is bound by human rights standards, to increase the level of human rights protection and to create an institution to monitor compliance. In the WTO, this dimension of constitutionalisation is completely absent. Although it could be argued that certain WTO policies potentially, even if only indirectly, affect or even infringe social or indigenous rights, especially in developing countries, these policies are not subject to any human rights review. Neither are the relevant standards agreed upon, nor are monitoring bodies available. The WTO dispute settlement bodies have no jurisdiction over their institutions. This difference between the (quasi-) compulsory jurisdiction of the WTO dispute settlement mechanism and the EU courts is, from a constitutionalist perspective, crucial.

\section{IV. (Judicial) constitutionalisation of and through WTO dispute settlement}

So far, the most viable aspect of micro-constitutionalisation is the judicialisation of dispute settlement. This trend is in the spotlight of the WTO constitutionalisation debate. There are a number of different aspects to this. In institutional terms, quasi-compulsory and quasi-judicial proceedings have been established and progressively entrenched, so that now quasi-binding, judgment-like awards are rendered.

A different constitutional element in dispute settlement is the participation of non-state actors, notably NGOs, which represent the concerns of global civil society. Granting them a voice in the process of judicial law-making allows them to influence the international legal process at least indirectly, and this constitutes a paradigm shift. However, after the Shrimp case, the panels and the Appellate Body - following the criticism of the WTO Members - have taken a restrictive posture in this regard,

39 The criticism has still been raised that the ECJ's human rights protection is rather weak, that it gives too much weight to the interests of European integration, and too generously allows human rights restrictions on these grounds. 
and admit amicus curiae briefs only when they are taken up in the parties' submissions. ${ }^{40}$

In substance, the case law of the panels and the Appellate Body arguably is beginning to display some characteristics ordinarily associated with constitutional case-law. ${ }^{21}$ Initially, the role of the panels and the Appellate Body corresponded to a contractual setting in which the institutions mechanically examined whether state conduct was in compliance with the agreements. In contrast, considerations of vertical separation and balance of powers, which have shaped domestic standards of review, were not overtly present in the context of the WTO. ${ }^{42}$ The dispute settlement institutions then began to borrow constitutional doctrines, such as the proportionality analysis. ${ }^{43}$ They have begun to take into consideration non-trade issues such as human rights and environmental protection, and apply the technique of balancing to determine which of the conflicting interests should prevail in the concrete case. Arguably, the conceptual development of a more constitutional framework would provide room for more nuanced and multilayered standard-of-review principles. ${ }^{44}$ Thomas Cottier has called this 'constitutionalism in a modest sense', 'an attitude and a framework capable of reasonably balancing and weighing different, equally legitimate and democratically defined basic values and policy goals. ${ }^{45}$

But this vision of WTO constitutionalism is subject to strong criticism. One objection is that by taking the principle of trade liberalisation as

40 Panel, US - Softwood Lumber (22 March 2004) WT/DS277/R, at 88, n. 75. Here the Panel stated that it would 'consider any arguments raised by amici curiae to the extent that these arguments were taken up in the written submissions and/or oral statements of any party or third parties'

41 D. Z. Cass, "The "constitutionalization" of international trade law: Judicial normgeneration as the engine of constitutionalization' (2001) 13 European Journal of International Law 42.

$42 \mathrm{M}$. Oesch, Standards of Review on WTO Dispute Resolution (Oxford University Press, 2003), p. 29 and pp. 241-242.

43 See for a balancing approach to the 'necessity' requirement of Art. XX(d) GATT, which grants an a priori equal rank to the conflicting objectives: $A B$, Korea - Measures Affecting Imports of Fresh, Chilled and Frozen Beef (11 December 2000) WT/DS161/AB/R, WT/DS169/AB/R, para. 162: "The more vital or important those common interts or values are, the easier it would be to accept as "necessary" a measure designed as an values are, the easier it

44 Oesch, Standards of Review, above note 42, p. 243.

45 T. Cottier, 'Limits to International Trade: The Constitutional Challenge', in The American Society of International Law (ed.), International Law in Ferment: A New Vision for Theory and Practice, Proceedings of the 94th Annual Meeting (Washington, DC, April 5-8, 2000), p. 221. a constitutional norm, the trade-off between the obligation to liberalise and the protection of non-trade concerns inevitably ends in a preference for free trade. Competing values enter into the picture only as narrow and carefully policed exceptions, and the onus is on the party which invokes the exception, say the critics. ${ }^{46}$ However, an important strand of WTO constitutionalism seeks precisely to counter this order of priorities. From that perspective, the competing values are not just exceptions to trade liberalisation, but are provisions to protect legitimate policy goals, which form an integral part of a well-balanced multilateral trading system and which should be acknowledged to have the same status as other constitutional principles. ${ }^{47}$

Also, WTO constitutionalists are accused of falsely dignifying the judicial balancing process, instead of admitting its political character. When a WTO panel invalidates an environmental protection scheme, constitutionalists might view this as the enforcement of higher (namely constitutional) law (of free trade). In reality, however, say the critics, this is a political decision by the panel which is presumably illegitimate because it replaces the policy balancing of domestic democratic institutions with the panel's own policy.

This objection brings us to the heart of the matter. The entire 'constitutionalisation' process has so far been adjudicative rather than deliberative. The WTO's capacity for legislative response to judicial constitutional engineering is muted, last but not least by the consensus practice. This again fuels the fundamental objection against the constitutionalist reading of WTO law mentioned above, namely that this reading condones an impoverished, legalist (judicially made), apolitical conception of constitution. Our conclusion on the constitutional status of WTO is that the WTO is so far only a modestly constitutionalised entity.

\section{The WTO: private or public interest? ${ }^{48}$}

In 1992, Kenneth W. Abbott addressed the institutional issues of the GATT in terms of 'private' and 'public' interests. ${ }^{49} \mathrm{He}$ used the term 'private' to

46 Howse and Nicolaidis, above note $9,75$.

47 T. Cottier and M. Oesch, International Trade Regulation, above note 4, p. 428 and p. 540

48 See for a comprehensive study of the ideas and notions of 'public interest' and 'common good' in international law: S. Peter, 'Public Interest' and 'Common Good' in International Law, forthcoming.

49 K. W. Abbott, 'GATT as a public institution: The Uruguay Round and beyond' (1992) 31 Brooklyn Journal of International Law 31. 
refer to the 'particular interests of the individual states'. The term 'public' was designed to describe the 'common interests of the nations forming the world trading community'. According to Abbott's paper, GATT members had misconceived the GATT as 'constituting a private interest community'. By way of contrast, the Uruguay round was about institutionalising a 'public interest' approach, characterised by the 'concern for the common interests of the community of trading nations'.

The WTO came into being in 1995. In the following years, 'public interest' groups identified the WTO as the preferred target in their fight against a globalised trade regime and its undesirable effects. From this perspective, the WTO posed a threat to 'public interest' issues and was not seen to be a 'public interest' organisation. ${ }^{50}$

The two uses of 'public interest' show that the term is not a synonym for constitutionalism in international law. Rather, three different approaches to 'public interest' should be distinguished, namely the communal approach, the sovereigntist approach and the constitutionalist approach. This section will focus on the interpretation of exception clauses in international law. These clauses reflect the tension between national public interest and international goals. Accordingly, the different approaches to public interest are mirrored in the way these clauses are interpreted by states or by international adjudication bodies. It is submitted that a constitutionalist understanding of these clauses must accept that they reflect national public interests.

\section{The communal approach to public interest}

\section{Public interest and private interest}

Abbott used the term 'public interest' to sketch the institutional change of the old GATT. He proposed that this change should imply a 'significantly increased role ${ }^{51}$ for the GATT institutions. Abbott's approach is based mainly on a domestic analogy. States are seen to be individual, unitary actors which pursue their own self-interest (private interest). On the other hand, international organisations adopt a 'public' view when they pursue a community vision, characterised by its independence from the party's visions. They are labelled 'public' because they are supposed to transcend the individual interests of their members. According to Abbott,

50 S. Picciotto, 'Defending the public interest in TRIPS and the WTO', in P. Drahos and R. Mayne (eds.), Global Intellectual Property Rights (Basingstoke: Palgrave Macmillan, 2002). 51 Abbott, 'GATT as a Public Institution', above note 49 , p. 84 . the GATT was 'created with a vision of the public good, a set of common goals, principles and norms (designed to restrain national autonomy)..$^{52}$ According to this view, the communal core of the GATT would lie in the restraint of 'national autonomy' for the greater good of enabling trade liberalisation. By way of contrast, the traditional (national) public interest in a borderless world ... has become little more than a cloak for subsidy and protection [and] has no meaningful place.53

\section{A communal interpretation of Article XX GATT}

Let us test a communal approach to Article XX GATT. Roughly speaking, a communal approach would imply that the overall interests of the trading system prevail over the individual interests of the Members. It is possible to see the Tuna Panels in this light. The US Marine Mammal Protection Act of 1972 required a general prohibition of the taking and importation into the US of marine mammals. Under the Act, the importation of commercial fish or fish products which resulted in the incidental killing of ocean mammals was prohibited. In Tuna I, Mexico claimed that the import prohibition on yellowfin tuna and tuna products was inconsistent with Articles III, XI, and XIII GATT. The US argued that the measure was covered by Articles XX(b) and (g) GATT. The Panel Report in Tuna $I$ expressed the fear that any justification under Article XX GATT might lead to 'green protectionism.54 Thus, the Panel considerably reduced the scope of this Article by excluding virtually all unilateral measures:

The Panel considered that if the broad interpretation of Article XX(b) suggested by the United States were accepted, each contracting party could unilaterally determine the life or health protection policies from which other contracting parties could not deviate without jeopardizing their rights under the General Agreement. The General Agreement would then no longer constitute a multilateral framework for trade among all contracting parties but woula provide legal security only in respect of trade between a limited number of contracting parties with identical internal regulations. ${ }^{55}$

52 Ibid. p. 38

$53 \mathrm{~K}$. Ohmae, The End of the Nation State: The Rise of Regional Economies (London: Harper Collins, 1996), p. 64

54 D. C. Esty, Greening the GATT: Trade, Environment, and the Future (Washington, DC: Institute for International Economics, 1994).

55 Panel Report, United States - Restrictions on the Imports of Tuna (not adopted) (3 September 1991) BISD 39S/1.55 para. 5.27. 
Although the Panel Reports on the Tuna cases were never adopted, these reports attracted wide attention and marked the beginning of the whole 'trade and environment' debate. ${ }^{56}$ The Tuna Panels suggested a communal reading of Article XX GATT which would have favoured the GATT values nearly unconditionally over non-trade interests. As a 'public' institution, the GATT system would be able to impose its trade values even against the 'private' interests of an individual Member. However, this communal 'public interest' reading of Article XX GATT did not find approval outside the trade community, which was blamed for having an insider understanding ${ }^{57}$ of trade.

In US - Shrimp, the Appellate Body rejected the communal approach to the public interest exceptions of Article XX GATT. Measures which fall under the scope of paragraph (a) to (j) of that Article were 'recognized as exceptions to substantive obligations established in the GATT 1994, because the domestic policies embodied in such measures have been recognized as important and legitimate in character ${ }^{58}$ Further, the Appellate Body has recognised ever since that it is for the Member to determine its own level of protection. However, protectionist measures remain outlawed. Members have to implement these measures in such a way as to satisfy the requirements of the chapeau of Article XX GATT.

\section{The sovereigntist approach to public interest}

1. 'Public interest' in limitation clauses and general exception clauses

States are public entities, inhabited by private individuals. However, Abbott used the public-private distinction in another way. He implicitly compared the behaviour of states to that of individual persons. In the international sphere, state autonomy and state sovereignty thus seem to correspond to the 'private', self-maximising behaviour of individuals.

However, opposing 'public interest' to state sovereignty does not reflect the use of the term in international law. Neither state autonomy nor state sovereignty are opposed to the concept of public interest in international

56 M. Matsushita, T. I. Schoenbaum and P. C. Mavroidis, The World Trade Organization. Law, Practice, and Policy (2nd edn, Oxford University Press, 2006), p. 794.

57 R. Howse, 'The Appellate Body rulings in the Shrimp/Turtle Case: A new legal baseline for the trade and environment debate' (2002) 27 Columbia Journal of Environmental Law 517.

58 Appellate Body Report, United States - Import Prohibition of Certain Shrimp and Shrimp Products (12 October 1998) WT/DS58/AB/R para. 21 law: quite the contrary. One important use of 'public interest' in international law is closely linked to state sovereignty. The term is explicitly used in Article 8 TRIPS and Article 1 of the First Additional Protocol of the European Convention on Human Rights (ECHR). Article 8 TRIPS allows Members to adopt measures necessary 'to promote the public interest in sectors of vital importance', whereas the peaceful enjoyment of possessions requires that no one 'shall be deprived of his possessions except in the public interest'. 'Public interest' is also an umbrella term for state interests such as the protection of public morals, public policy or safety, public (or national) security or the protection of human, animal or plant life or health. These interests are frequently invoked in international law as treaty exceptions such as Articles XX and XXI GATT and Article XIV $\mathrm{GATS}^{59}$ or Article $30 \mathrm{EC}$

\section{A sovereigntist interpretation of Article XXI GATT: a self-judging obligation}

From a historical perspective, escape clauses, ordre public reservations ${ }^{60}$ or 'vital interest' clauses ${ }^{61}$ reflect the priority claim of state sovereignty. ${ }^{62}$ The strong sovereigntist background of these clauses can amount to claims that they are 'self-judging. 'Self-judging' obligations are considered as being able to block judicial review. The most prominent example of an alleged self-judging obligation is Article XXI GATT, the national security exception. Under GATT 1947, several disputes arose under this Article. The question whether the mere invocation of Article XXI GATT blocks any review process under Article XXIII GATT remained unsettled throughout the GATT years. ${ }^{63}$ Although states no longer contest the jurisdiction of panels, recent cases support the view that states prefer to settle disputes which involve national security issues outside the framework of the

59 See also T. Cottier, R. Delimatsis and N. F. Diebold, 'Commentary on Art. XIV GATS' in R. Wolfrum, P.-T. Stoll and C. Feinäugle (eds.), Max-Planck Commentaries on World Trade Law, Vol. 6: WTO - Trade in Services (Leiden: Martinus Nijhoff, 2008), pp. 283-328.

60 Ibid.

61 M J Hahn 'Vital interests in the law of the GATT: An analysis of GATT's security exception' (1991) 12 Michigan Journal of International Law 558.

62 A. Emmerson, 'Conceptualizing security exceptions: Legal doctrine or political excuse?' (2008) 11 Journal of International Economic Law 135.

63 P. Lindsay, 'The ambiguity of GATT Article XXI: Subtle success or rampant failure?' (2003) 52 Duke Low Journal 1279; S. Rose-Ackermannn and B. Billa, 'Treaties and national security' (2008) 40 New York University Journal of International Law and Politics 467. 
WTO ${ }^{64}$ By contrast, scholarly writings point to other international treaty organs such as the European Court of Human Rights (ECtHR) or the European Court of Justice to show that national security issues are not per se outside the realm of judicial review. Indeed, in its very first case, the ECtHR established its jurisdiction on Article 15 ECHR, involving the full reviewability of the requirements which allow a state to invoke derogation measures. ${ }^{65}$ It rejected thereby the claim of the Irish Government that 'it was for a Government, and for that Government alone, to determine when a state of emergency existed and what measures were required by the exigencies of the situation. ${ }^{56}$

\section{The constitutionalist approach to public interest}

1. International adjudication on sovereigntist clauses The ECtHR Lawless ruling has been compared to the seminal judgment of Marbury v. Madison in which the US Supreme Court asserted its power to review the constitutionality of legislative acts and thus the legitimacy of constitutional judicial review. ${ }^{67}$ Indeed, the ECtHR has adopted the view that the Convention was not merely one international treaty among several others but 'a constitutional instrument of European public order (ordre public) ${ }^{68}$ Similarly, the constitutionalisation of the European Union is closely linked to the ECJ's jurisprudence. Besides the doctrines of supremacy and direct effect of EC law, the Court's case law on the fundamental freedoms has significantly contributed to the constitutionalisation

64 Two disputes have arisen so far under the WTO. In 1996, a dispute arose between the $\mathrm{EC}$ and the US on the so-called 'Helms-Burton' Act. The dispute was settled bilaterally in a Memorandum of Understanding although a WTO panel had previously been established. European Union - United States: Memorandum of Understanding Concerning the U.S. Helms-Burton Act and the U.S. Iran and Libya Sanctions Act (11 April 1997) 36 ILM 529 (1997). The other dispute involving Art. XXI GATT arose between Nicaragua and Columbia. In Nicaragua-Measures affecting Imports from Honduras and Columbia, Columbia requested the establishment of a panel, challenging a Nicaraguan law which imposed sanctions on Columbia and Honduras. The Dispute Settlement Body agreed to the establishment of a panel; however, it appears that it was never constituted. WTO Dispute Settlement Body: Minutes of Meeting held on 18 May 2000, WTO Doc WT/DSB/M/80 (26 June 2000) para 40

65 Lawless v. Ireland (App no 332/57) (1961) Series A no. 3 para. 22.

66 Lawless v. Ireland (App no 332/57) (1959) Report of the Commission pp. 78-79.

$67 \mathrm{~F}$. Ni Aolain, 'The emergence of diversity: Differences in human rights jurisprudence' (1995) 19 Fordham International Law Journal 111.

68 Loizidouv. Turkey (Grand Chamber) (App no 15318/89) Series A no. 310 para. 75. of Community law. ${ }^{69}$ Further, much of the debate about the constitutionalisation of the WTO is linked to the strengthened institutional role of the 'judicialised' dispute settlement system in general ${ }^{70}$ or more specifically to a suggested approach to the adjudication of Article XXI GATT. ${ }^{71}$ The constitutionalist vocabulary is thus closely linked to the existence of international adjudication on clauses which enshrine national public interest concerns.

2. A constitutionalist interpretation of exception clauses: accepting national 'collective preferences'

A constitutionalist interpretation of exception clauses recognises that they reflect 'collective preferences'. The concept of 'collective preferences' was introduced by Pascal Lamy in the context of WTO law as a way in which to address the discomfort felt with free trade rules. ${ }^{72} \mathrm{He}$ suggested introducing an additional safeguard clause which would allow WTO Members to escape trade obligations provided that they pay compensation in order to adjust the trade system. The problems of such a 'collective preference' safeguard clause are manifold. ${ }^{73}$ However, Lamy's term 'collective preferences' merits approval because it makes it clear that states are collectivities. In a state-based system, national communities are forced to speak with one voice and to represent one 'single identity?. ${ }^{74}$ It is the State "which has the exclusive authority to bind the whole community to international law. ${ }^{75}$ But what is the national interest or the public interest of a national community? Lamy advocates domestic procedures which should prove the genuineness of the collective preferences but does not elaborate on the

69 A. Peters, Elemente einer Theorie der Verfassung Europas (Veröffentlichungen des WaltherSchücking-Instituts für Internationales Recht an der Universität Kiel. Berlin: Duncker \& Humblot, 2001), pp. 406-408.

70 Cass, 'The "constitutionalization" of international trade law' above note $41,39$.

71 H. L. Schloemann and S. Ohlhoff, "Constitutionalization" and dispute settlement in the WTO: National security as an issue of competence' (1999) 93 The American Journal of International Law 424 .

$72 \mathrm{P}$. Lamy, "The emergence of collective preferences in international trade: Implications for regulating globalisation', speech given on 15 September 2004 (available at http://ec. europa.eu/archives/commission_1999_2004/lamy/speeches_articles/spla242_en.htm, 15 April 2009).

73 S. Charnovitz, 'An analysis of Pascal Lamy's proposal on collective preferences' (2005) 8 Journal of International Economic Law 449.

74 S. Burchill, The National Interest in International Relations Theory (Basingstoke: Palgrave, 2005), p. 47.

75 Ibid., p. 55. 
details of such procedures. Steve Charnovitz has rightly shown the diffculties which arise from this 'piercing of the unitary member.76 Although the demand for more domestic public deliberation on trade issues merits approval, it is difficult to imagine how the WTO could objectively verify the existence of collective preferences. ${ }^{77}$ Further, it is difficult to see why the domestic procedures should only apply in cases relating to trade exceptions and not to the negotiation of trade rules. ${ }^{78}$

The need to verify the genuineness of 'collective preferences' in trade law stems from the fear that the national 'public interest' is protectionism in disguise and that the concept itself is always hijacked by domestic rentseeking groups. Therefore, international courts engage in a very close textual analysis of the different public interest exceptions when they adjudicate trade rules. The scope of the exception clauses is interpreted rather narrowly ${ }^{79}$ whereas the scope of those provisions which can be violated is interpreted rather widely. In EC law, the scope of Article $28 \mathrm{EC}$ was widened to such an extent that the original rules of non-discrimination have developed into rules of de-regulation. However, the widening of the scope of Article $28 \mathrm{EC}$ has occurred alongside the introduction of additional public interest defences, namely the 'mandatory requirements ${ }^{30}$ or the 'overriding requirements of general public importance.81 These court-made exceptions are interpreted in a flexible way that has allowed the Court to acknowledge additional public interests such as consumer protection, ${ }^{82}$ environmental protection ${ }^{83}$ or human rights protection. ${ }^{84}$ No additional public interest defences have been introduced so far in WTO law and no exceptions have been developed which could be compared to

76 Charnovitz, 'An analysis of Pascal Lamy's proposal on collective preferences', above note 73, p. 456.

77 Ibid., p. $458 . \quad 78$ Ibid., p. 456

79 See for example: Panel Report EC - Conditions for the Granting of Tariff Preferences to Developing Countries (1 December 2003) WT/DS246/R paras. 7.2077.210. The panel found that the European drug arrangements were not covered by 7.210. The

80 ECJ, Case 120/78 Rewe-Zentrale AG v. Bundesmonopolverwaltung für Branntwein [1979] ECR 649 para. 8.

81 ECJ, Case C-34/95 Konsumentombudsmannen (KO) v. De Agostini [1997] ECR I-3843 para. 46.

82 ECJ, Case $120 / 78$ Rewe-Zentrale AG v. Bundesmonopolverwaltung für Branntwein [1979] ECR 649.

83 EC), Case 302/86 Commission v. Kingdom of Denmark [1988] ECR 4607 paras. 8-9.

84 ECJ, Case C-112/00 Eugen Schmidberger, Internationale Transporte und Planzügev. Republik Österreich [2003] ECR I-5659 para. 74 the concept of 'mandatory requirements. ${ }^{85}$ Therefore, scholars argue for broad interpretations of the various subparagraphs of Article XX GATT. Article XX(a) GATT, in particular, which provides for the protection of public morals, was considered to allow for the inclusion of concerns such as the protection of human rights. ${ }^{86}$

\section{Preliminary outlook}

Far from saying that the international adjudicating bodies are constitutional courts, it can be submitted that their case law on 'public interest' as enshrined in the relevant exceptions or limitation clauses offers important insight into the legitimacy of international law adjudication. When exception clauses are interpreted in a communal way, the overall 'public interest' of the treaty system prevails almost unconditionally over the 'public interest' issues which are addressed in these clauses. When they are interpreted in a sovereigntist way, the definition of 'public interest' is left entirely up to the individual parties to the treaty. This may pose a threat to the treaty system because the exception 'ceases to be a rule of law and becomes a maxim of politics. ${ }^{87}$ What is needed, thus, is a way to address the clauses which mediates between the two extremes. European Courts, both the ECtHR and the ECJ, refer to an explicit or implied doctrine of 'margin of appreciation'. This doctrine mitigates the possible impacts of international law on the national public interest, thereby strengthening the Court's own political legitimacy. ${ }^{88}$

The constitutionalist reconstruction of international law should not claim that international law and international institutions always promote 'public interests', whereas States merely act in their own narrowly defined self-interest. The constitutionalist approach to public interest in international law takes into account that public interest exceptions refer to interests which are in principle recognised as legitimate interests of collective actors. Nevertheless, the decision as to whether a Member's measure

85 Cottier, Deiimatsis and Diebold, 'Commentary on Art. XIV GATS', above note 59, pp. $283-328$

86 S. Charnovitz, 'The moral exception in trade policy' (1998) 38 Virginia Journal of International Law 689; N. F. Diebold, 'The morals and order exceptions in WTO Law: Balancing the toothless tiger and the undermining mole' (2008) 11 Journal of International Economic Law 43.

$87 \mathrm{H}$. Lauterpacht, Private Law Sources and Analogies of International Law (London: Longmans, Green \& Co., 1927), p. 169

88 D. Shelton, 'The boundaries of human rights jurisdiction in Europe' (2003) 13 Duke Journal of Comparative es International Law 95, p. 135. 
is covered by the exception is left to an international adjudication body which is charged with the interpretation of these exceptions.

\section{E. Policy recommendations}

Further constitutionalisation could be realised by political actors and promoted by doctrinal arguments along the following lines.

\section{Constitutional substance}

The libertarian inclination of the nascent WTO constitution should be rectified by strengthening the legal relevance of non-trade issues such as environmental and social concerns. The constitutional principle of solidarity should be implemented by promoting liberalisation in sectors in which poor countries can compete.

The so-called 'new, new issues' of the WTO, namely the rule of law, good governance, corruption, corporate responsibility, exchange rates and migration, should be promoted, because these are all issues that deserve the label 'constitutional' on account of their fundamental nature, and are indeed typically dealt with in state constitutions.

Furthermore, it would be appropriate to strengthen the WTO constitutional restraints on Members. This means that direct access of private (business) actors to W'TO dispute settlement and the functionally equivalent route, namely traders' access to domestic courts with the complaint that WTO law has been breached by a Member, should be re-examined.

\section{Access of private actors to WTO dispute settlement and} to domestic courts

Direct access of private parties to the WTO dispute settlement institutions would liberate business actors from the tutelage of their governments, which are often reluctant to institute WTO proceedings. The governmental choice of whether to bring or not to bring a particular WTO case to the dispute settlement forum is often not guided by the importance and meritoriousness of the issue, but is influenced by diplomatic considerations on the general relations with another country, by a desire to leave a legal question undecided, or by the lobbying power or weakness of an industry sector. These policy considerations neglect the rule of law and they lead to unequal treatment of business actors.
The privatisation of WTO dispute settlement would remedy these problems and lead to better respect for the rule of law and equal protection. Because self-interested commercial actors have a strong incentive to sue, it would moreover strengthen the GATT by terminating underenforcement. It would finally relieve governments of the burden of political tensions.

But such privatisation may be a step too far. Given that the military option is largely foreclosed, economic and trade regulation is nowadays the main foreign policy instrument of governments. ${ }^{89}$ The regulation of trade flows is intrinsically dualist: it concerns both the public and private interests. Governments litigating before the WTO dispute settlement institutions are therefore often counselled by the interested business actors. This duality should be more clearly acknowledged and regulated under due consideration for the public and private concerns at stake. For instance, one could question the extent to which the interest in business secrecy, which is protected through the non-disclosure of business confidential information by the litigating states parties, ${ }^{90}$ really outweighs the public interest in transparency and publicity of the WTO proceedings. Ultimately, it must be kept in mind that the public and the private interests at stake need not coincide. The appropriate constitutional design of WTO dispute settlement therefore seems not to be to remove it completely from governmental control, but to uphold it as a basically inter-state system while greatly increasing and formalising the participatory opportunities of private actors.

In parallel, the direct application of suitable WTO rules should be reconsidered..$^{91}$ Admittedly, the direct application of WTO law risks giving undue power to domestic courts to the detriment of the Members' political branches. Also, as long as WTO law has not fully integrated legitimate policy concerns other than trade liberalisation, the 'unfiltered' application of WTO law by domestic courts may threaten those policy

89 T Cottier in a panel discussion moderated by P. C. Mavroidis, 'Is the WTO dispute settlement mechanism responsive to the needs of traders? Would a system of direct adjudication by private parties yield better results?' (1998) 32 yournal of World Trade 147, p. 154.

90 Panel, Canada - Measures Affecting the Export of Civilian Aircraft (14 April 1999) WT/DS70, para 9.68 and Appellate Body, Canada - Measures Affecting the Export of Civition Aircraft (2 August 1999) WT/DS70/AB/R, paras. 141 et seq.

91 See T. Cottier, 'A theory of direct effect in global law', in A. von Bogdandy, P. C. Mavroidis, and $Y$. Mény (eds.), European Integration and International Co-ordination. Studies in Transnational Economic Law in Honour of Claus-Dieter Ehtermann (The Hague: Kluwer Law International, 2002), pp. 99-123. 
concerns. ${ }^{92}$ Finally, it can be argued that the development of WTO law by domestic judges, triggered by private claimants, must be accompanied (and eventually corrected) by WTO rule-making processes in which these private actors can participate.

Ultimately, the constitutionalist agenda encourages a more ready acceptance of the direct effect of suitable provisions of WTO law, because direct effect would enable the domestic judiciary to check the Members' executives, which otherwise enjoy unfettered discretion in applying the rules which were actually designed to restrain these very actors. This is the classic theme of constitutionalism, which seeks to contain political power in order to safeguard the autonomy of the individual. From a constitutionalist perspective, the enactment of a WTO decision that would define the criteria of direct applicability, clarify who is entitled to invoke direct effect, and explicitly allow the direct effect of WTO provisions satisfying the established criteria, is recommended. Provisions suited for direct effect are in essence those whose concretisation can, under a theory of delegation informed by the rule of law, be legitimately delegated to a judge. ${ }^{93}$ But because the application of those WTO norms by domestic courts bears the risk of diverging case law, the admission of direct effect would ideally be accompanied by a system of referral to the international adjudicative organs for preliminary rulings in order to harmonise the interpretation of WTO law.

\section{A multilevel judiciary}

A constitutionalist approach to the judiciary permits us to appraise the WTO dispute settlement institutions and the national courts as forming one multilevel judiciary. From this perspective, the activity at both levels should be informed by constitutionalism and the rule of law, and the intensity of judicial review should be adapted to the degree of integration of their subsystem. ${ }^{94}$ The WTO panels' attitude would need to shift to a more constitutionalist approach which would allow for a more refined balancing between market access rights and other legitimate policy concerns. In contrast, national courts should adopt a stricter standard of review for scrutinising the trade policy decisions of their executives.

92 Cottier, 'Direct effect', above note 91, pp.114-115.

93 Ibid., Pp. 118-119.

94 T. Cottier and P. Mavroidis, 'Concluding remarks', in T. Cottier and P. Mavroidis (eds.), The Role of the Judge in International Trade Regulation: Experience and Lessons for the WTO (Ann Arbor: Michigan University Press, 2003), pp. 349, 353

\section{Political and legal accountability}

In institutional and procedural terms, the accountability of WTO activities should be enhanced. As far as legal accountability is concerned, judicial review of acts of the institutions themselves must be made available in the long run. In terms of political accountability, the involvement of non-state actors in the elaboration of 'secondary' trade law and dispute settlement should be further strengthened in order to increase transparency and to introduce elements of participatory democracy. Concerns about NGOs' legitimacy and accountability and about ineffectiveness of procedures could be allayed by an accreditation scheme which must be as far as possible depoliticised. ${ }^{95}$ Besides, a parliamentary dimension could be introduced into the WTO. ${ }^{96}$ This should be done both on the national level (liaising better with national parliaments), and on the international level by creating an informal network of national parliaments which might in the long run lead to a standing parliamentary assembly. Members which do not have a parliament could be allowed to send other officials to these meetings.

\section{Law- and decision-making}

Finally, and most importantly, we face inertia in the creation of primary WTO law (i.e. the amendment of the WTO treaties themselves ${ }^{97}$ ) and secondary law. ${ }^{98}$ More effective WTO rule-making and decision-making

95 See the Guidelines for arrangements on relations with Non-Governmental Organizations, WT/L/162, Decision of 18 July 1996. WTO Director-General Supachi Panitchpakdi established two informal advisory bodies to the WTO Secretariat in 2003, as a platform established two informal advisory bodies to the WTO Secretariat in 2003 , as a platform Director-General disbanded these informal bodies. See P. van den Bossche, 'NGO involvement in the WTO: A comparative perspective' (2008) 11 Journal of International Economic Law 717.

96 Proposals along these lines are supported by the IPU and the European Parliament, but are opposed by the USA and many developing countries. See the parliamentary conference on the WTO convened by the European parliament and IPU calling for a parliamentary dimension to the WTO (Final declaration of 18 February 2003). See G. Shaffer, 'Parliamentary Oversight of WTO-Rulemaking? The Political, Normative, and Practical Contexts' (2004) 7 Journal of International Economic Law 629; E. Mann, 'Parliamentary dimensions in the WTO - More than just a vision?' (2004) 7 Journal of International Economic Law 659.

97 See into WTO negotiations, T. Cottier, 'Structural reform of the WTO' (2007) 10 Journal of International Economic Law 497, pp. 505-506.

98 See on this problem Y. Bonzon, M. Elsig, M. Foltea, T. Messerli and A. Ziegler, 'Reflections on Modes of Decision-Making in the WTO', Chapter 2 in this volume. 
is needed for two reasons. First, only treaty revision can bring about positive social and environmental integration, which is not yet ingrained in the treaties and which can therefore not be effected by the judiciary alone. Second, the possibility of a legislative response to adjudication is required to counter the problem of a presumably illegitimate government of judges, and to enhance the balance of powers within the WTO.

The current WTO practice for decision-making and rule-making relies on the consensus principle (footnote 1 of the WTO Agreement). Although Article IX. WTO Agreement provides for majority voting if a consensus is not reached (with decisions to be adopted upon a simple majority of the votes cast), such voting does not take place. The current consensus practice is ineffective because it risks cementing the status quo. From a constitutionalist perspective, it is even more important that this practice is also illegitimate. It is undemocratic because it allows one WTO Member to tyrannise the others, and allows a small minority or one Member to block collective action. ${ }^{99}$ It is also anti-egalitarian, because it gives more weight to the positions of Members who are less likely to give up their resistance, and these tend to be the bigger and richer ones. ${ }^{100}$ Finally, the resulting unavailability of a legislative response to the (quasi-) judicial decisions leaves the dispute settlement institutions uncontrolled and thereby undermines the legitimacy of the WTO judiciary.

One possible reform that would enhance the effectiveness and legitimacy of decision-making would be the introduction of weighted voting. ${ }^{101}$ Such a reform would make transparent the undeniable preponderance of the powerful Members, while still being more acceptable to the powerful Members than a system of equal votes. However, it is exceedingly difficult to identify the appropriate factors for weighting the votes. From a radically democratic perspective, the decisive criterion would have to be the size of population in order to represent more fairly the world's citizens who are the ultimate unit of global democracy. But other factors reasonably related to the mandate of the WTO, such as shares of world trade and openness of the markets, also seem relevant.

99 Cf. Francisco de Vitoria 'On Civil Power', in Political Writings [1528], ed. by A. Pagden and J. Lawrence (Cambridge University Press, 1991), pp. 1-44, p. 30 (para. 14)

100 C. D. Ehlermann and L. Ehring, 'Decision making in the world trade organization: Is the consensus practice of the world trade organization adequate for making, revising and implementing rules on international trade?' (2005) 8 Journal of International Economic Law 51, p. 66.

$101 \mathrm{~T}$. Cottier and S. Takenoshita, 'The balance of power in WTO decision-making: Towards weighted voting in legislative response' (2003) 59 Aussenwirtschaft 171
An alternative strategy would be to change the decision-making practices without formally amending the decision-making rules. The first option along this route is to eliminate the taboo against voting, and thereby revive the legally available possibility of voting. This 'shadow'of voting would probably induce Members to give up their veto more often and would thus facilitate consensual decision making. ${ }^{102}$ Another possibility would be to revitalise the so far underused rule 33 of the various WTO bodies' Rules of Procedure. ${ }^{103}$ These rules state that when consensus is not reached in councils, committees, and other subordinate bodies, the decision should be moved up to the General Council. Finally, the option of authentic interpretation under Article IX(2) WTO Agreement could be used more often. ${ }^{104} \mathrm{~A}$ decision defining the authentic interpretation of any WTO law provision can be taken by the Ministerial Conference and the General Council with the votes of three-quarters of the Members and will bind all WTO Members. While Article IX(2) WTO Agreement states that authentic interpretation must not undermine the amendment provisions of Article X WTO Agreement, this limit still leaves considexable leeway for fine-tuning the WTO provisions, and also for correcting an interpretation given by a panel or Appellate Body. While the principal constitutional challenges for the WTO lie in its rule-making and decisionmaking, we submit that the WTO could and should be constitutionalised further along the proposed lines.

\section{Bibliography}

Abbott, Kenneth W., 'GATT as a public institution: The Uruguay Round and beyond' (1992) 31 Brooklyn Journal of International Law 31

Amerasinghe, Chittharanjan Felix, Principles of the Institutional Law of International Organizations, 2nd edn (Cambridge University Press, 2005).

Armingeon, Klaus and Milewicz, Karolina, 'Compensatory constitutionalisation: A comparative perspective' (2008) 22 Global Society 179.

Van Den Bossche, Pieter, 'NGO involvement in the WTO: A comparative perspective' (2008) 11 Journal of International Economic Law 717.

Burchill, Scott, The National Interest in International Relations Theory (Palgrave: Basingstoke, 2005).

102 Ehlermann and Ehrig, above note 100, pp. 72-73. See for a discussion on which types of W'TO decisions can legitimately be made non-consensually Bonzon et al., above note 98, at section D.III.

103 Ehlermann and Ehrig, above note 100, pp. 73-74.

104 Ibid., pp. 58-59. 
Cass, Deborah Z., "The "constitutionalization" of international trade law: Judicial norm-generation as the engine of constitutional development in international trade' (2001) 12 Journal of International Economic Law 39.

Cass, Deborah Z., The Constitutionalization of the WTO (Oxford University Press, 2005).

Charnovitz, Steve, 'The moral exception in trade policy' (1998) 38 Virginia Joumal of International Law 689.

Charnovitz, Steve, 'An analysis of Pascal Lamy's proposal on collective preferences' (2005) 8 Journal of International Economic Law 449.

Cottier, Thomas, 'Is the WTO dispute settlement mechanism responsive to the needs of traders? Would a system of direct adjudication by private parties yield better results?' (1998) 32 Journal of World Trade 147.

Cottier, Thomas, 'Limits to international trade: The constitutional challenge', in The American Society of International Law (ed.), International Law in Ferment: A New Vision for Theory and Practice, Proceedings of the 94th Annual Meeting (Washington, DC, April 5-8, 2000), pp. 220-222.

Cottier, Thomas, 'A theory of direct effect in global law', in A. von Bogdandy, P. C. Mavroidis, Y. Mény (eds.), European Integration and International Co-ordination. Studies in Transnational Economic Law in Honour of Claus-Dieter Ehlermann (The Hague: Kluwer Law International, 2002), pp. 99-123.

Cottier, Thomas, 'Trade and human rights: A relationship to discover' (2002) 5 Journal of International Economic Law 111.

Cottier, Thomas, 'Structural Reform of the WTO' (2007) 10 Journal of International Economic Law 497.

Cottier, Thomas and Takenoshita, Satoko, 'The balance of power in WTO decisionmaking: 'Towards weighted voting in legislative response' (2003) 59 Aussenwirtschaft 171.

Cottier, Thomas and Mavroidis, Petros, 'Concluding remarks', in T. Cottier and P. Mavroidis (eds.), The Role of the Judge in International Trade Regulation: Experience and Lessons for the WTO (Ann Arbor: Michigan University Press, 2003), pp. 349-357.

Cottier, Thomas and Hertig, Maya, 'The Prospects of 21st Century Constitutionalism' (2003) 7 Max Planck Yearbook of United Nations Law 261.

Cottier, Thomas and Oesch, Matthias, International Trade Regulation: Law and Policy in the WTO, The European Union and Switzerland: Cases, Materials and Comments (Staempfli: Bern, 2005).

Cottier, Thomas, Delimatsis, Panagiotis and Diebold, Nicolas F., 'Commentary on Art. XIV GATS', in R. Wolfrum, P.-T. Stoll and C. Feinäugle (eds.), MaxPlanck Commentaries on World Trade Law, Vol. 6: WTO - Trade in Services (Leiden: Martinus Nijhoff, 2008), pp. 283-328.
Delimatsis, Panagiotis, International Trade in Services and Domestic Regulations: Necessity, Transparency, and Regulatory Diversity (Oxford University Press, 2007).

Diebold, Nicolas F., "The morals and order exceptions in WTO Law: Balancing the toothless tiger and the undermining mole' (2008) 11 Journal of International Economic Law 43.

Downs, George W., Rocke, David M. and Barsoom, Peter N., 'Is the good news about compliance good news about cooperation?’ (1996) 50 International Organization 3.

Dunoff, Jeffrey, "Constitutional conceits: The WTO's "constitution" and the discipline of international law' (2006) 17 European Journal of International Law 647.

Ehlermann, Claus Dieter and Ehring, Lothar, 'Decision making in the World Trade Organization: Is the consensus practice of the World Trade Organization adequate for making, revising and implementing rules on international trade? (2005) 8 Journal of International Economic Law 51.

Elsig, Manfred, 'The World Trade Organization's legitimacy crisis: What does the beast look like?' (2007) 41 Journal of World Trade 75.

Emmerson, Andrew, 'Conceptualizing security exceptions: Legal doctrine or political excuse?' (2008) 11 Journal of International Economic Law 135.

Esty, Daniel C., Greening the GATT: Trade, Environment, and the Future (Institute for International Economics, Washington, DC, 1994).

Esty, Daniel C., 'The World Trade Organization's legitimacy crisis' (2002) I World Trade Review 7.

Føllesdal, Andreas, "When "common interests" are not common: Why the "Global Basic Structure" should be democratic' (2009) 16 Indiana Journal of Global Legal Studies 585.

Gerhart, Peter M., 'The WTO and participatory democracy: The historical evidence' (2004) 37 Vanderbilt Journal of Transnational Law 897.

Hahn, Michael J., "Vital interests in the law of the GATT: An analysis of GATT's security exception' (1991) 12 Michigan Journal of International Law 558.

Howse, Robert, 'The legitimacy of the World Trade Organization', in Jean Marc Coicaud and Veijo Heiskanen (eds.), The Legitimacy of International Organizations (New York: United Nations University Press, 2001) pp. 355-407.

Howse, Robert, 'The Appellate Body rulings in the Shrimp/Turtle Case: A new legal baseline for the trade and environment debate' (2002) 27 Columbia Journal of Environmental Law 491.

Howse, Robert and Nicolaidis, Kalypso, 'Enhancing WTO legitimacy: Constitutionalization or global subsidiarity' (2003) 16 Governance 73.

Jackson, John H., World Trade Law and the Law of GATT (Indianapolis: Bobbs Merrill, 1969). 
Jackson, John H., 'Fragmentation or unification among international institutions: The World Trade Organization' (1999) 31 New York University Journal of International Law and Politics 823.

Klabbers, Jan, Peters, Anne and Ulfstein, Geir, The Constitutionalization of International Law (Oxford University Press, 2009).

Krajewski, Markus, 'Democraticlegitimacy and constitutional perspectives of WTO law' (2001) 35 Journal of World Trade 167.

Krajewski, Markus, 'International organizations or institutions, democratic legitimacy', Max Planck Encyclopedia of International Law (Oxford University Press, online edition [mpepil.com] 2009).

Lamy, Pascal, 'The emergence of collective preferences in international trade: Implications for regulating globalisation', speech given on 15 September 2004 (available at http:/ec.europa.eu/archives/commission_1999_2004/ lamy/speeches_articles/spla242_en.htm, 15 April 2009).

Lindsay, Peter, "The ambiguity of GATT Article XXI: Subtle success or rampant failure?' (2003) 52 Duke Law Journal 1277

Mann, Erika, 'Parliamentay dimensions in the WTO - More than just a vision?' (2004) 7 Journal of International Economic Law 659-665.

Matsushita, Mitsuo, Schoenbaum, Thomas J. and Mavroidis, Petros C., The World Trade Organization. Law, Practice, and Policy, 2nd edn (Oxford University Press, 2006).

McGinnis, John and Movsesian, Mark, 'The World Trade Constitution' (2000) 114 Harvard Law Review 511.

Milewicz, Karolina, 'Emerging patterns of global constitutionalization: Towards a conceptual framework' (2009) 16 Indiana Journal of Global Legal Studies 2.

Milewicz, Karolina, Bächtiger, André and Nothdurft, Arne, 'Constitutional pluralism or constitutional unity? An empirical study of international commitment (1945-2007)' (2010) 36 Review of International Studies 305-336.

Monaco, Riccardo, 'Le caractère constitutionnel des actes institutifs d'organisations internationales', in Mélanges offerts à Charles Rousseau: La communauté internationale (Paris: Pédone, 1974), pp. 153-172.

Ni Aolain, Fionnuala, 'The emergence of diversity: Differences in human rights jurisprudence' (1995) 19 Fordham International Law Journal 101.

Oesch, Matthias, Standards of Review on WTO Dispute Resolution (Oxford University Press, 2003).

Ohmae, Kenichi, The End of the Nation State: The Rise of Regional Economies (London: Harper Collins, 1996).

Peter, Simone, 'Public Interest' and 'Common Good' in International Law (forthcoming).

Peters, Anne, Elemente einer Theorie der Verfassung Europas (Veröffentlichungen des Walther-Schücking-Instituts für Internationales Recht an der Universität Kiel (Berlin: Duncker \& Humblot, 2001).
Peters, Anne, 'Compensatory constitutionalism: The function and potential of fundamental international norms and structures' (2006) 19 Leiden Journal of International Law 579.

Peters, Anne, 'The constitutionalisation of the European Union - Without the constitutional treaty', in S. P. Riekmann and W. Wessels (eds.), The Making of a European Constitution (Wiesbaden: VS Verlag für Sozialwissenschaften, 2006), pp. 35-67.

Petersmann, Ernst-Ulirich, "Time for a United Nations "Global Compact" for integrating human rights into the law of worldwide organizations: Lessons from European Integration' (2002) 13 European Journal of International Law 621.

Petersmann, Ernst-Ulrich, 'Multilevel judicial governance of international trade requires a common conception of rule of law and justice' (2007) 10 Journal of International Economic Law 529-552.

Picciotto, Sol, 'Defending the public interest in TRIPS and the WTO', in P. Drahos and R. Mayne (eds.), Global Intellectual Property Rights (Basingstoke: Palgrave Macmillan, 2002), pp. 224-243.

Preuss, Ulrich K., 'Equality of states - Its meaning in a constitutionalized global order' (2008) 9 Chicago Journal of International Law (2008) 17.

Rose-Ackermannn, Susan and Billa, Benjamin, 'Treaties and national security' (2008) 40 New York University Journal of International Law and Politics 437.

Schloemann, Hannes L. and Ohlhoff, Stefan, "Constitutionalization" and dispute settlement in the WTO: National security as an issue of competence' (1999) 93 American Journal of International Law 424.

Shaffer, Gregory, Defending Interests: Public-Private Partnerships in WTO-Litigation (Washington, DC: Brookings Institution Press, 2003)

Shaffer, Gregory, 'Parliamentary oversight of WTO-Rulemaking? The political, normative, and practical contexts' (2004) 7 Journal of International Economic Law 629-654.

Shelton, Dinah, 'The boundaries of human rights jurisdiction in Europe' (2003) 13 Duke Journal of Comparative \& International Law 95.

Simmons; Beth, Mobilizing for Human Rights: International Law in Domestic Politics (Cambridge University Press, 2009).

Trachtman, Joel P., 'The constitutions of the WTO' (2006) 17 European Journal of International Law 623.

Vitoria, Francisco de, Political Writings [1528], ed. by A. Pagden and J. Lawrance (Cambridge University Press, 1991).

Walker, Neil, 'The EU and the WTO: Constitutionalism in a new key', in Grainne de Burca and Joanne Scott (eds.), The EU and the WTO: Legal and Constitutional Issues (Hart: Oxford, 2001), pp. 31-57.

Zangl, Bernhard, 'The rule of law: Internationalization and privatization', in S. Leibfried and M. Zürn (eds.), Transformations of the State? (Cambridge University Press, 2005), pp. 73-91. 
Zangl, Bernhard, Die Internationalisierung der Rechtsstaatlichkeit. Streitbeilegung in GATT und WTO (Frankfurt am Main: Campus, 2006).

Zürn, Michael, 'Institutionalisierte Ungleichheit in der Weltpolitik: Jenseits der Alternativen "Global Governance" versus "American Empire" (2007) 48 Politische Vierteljahresschrift 680. 